\title{
The Medieval Origins of Capitalism in the Netherlands
}

BAS VAN BAVEL | UTRECHT UNIVERSITY

\begin{abstract}
Large parts of the Netherlands saw an early rise in market traffic during the late Middle Ages already. Exchange via the market became the dominant form not only for goods, but also for land, labour and capital, and this during the course of the sixteenth century already. This contribution investigates why it should be that the market form of exchange arose so early here specifically; how markets were organised as institutions and how they functioned. It will be demonstrated that the markets here had a favourable organisation, with low transaction costs, a high level of integration of the markets and a large degree of certainty for parties entering these markets. Nevertheless, the consequences of the rise of the market were not all positive. The rise of a market economy did not lead to any appreciable economic growth, while the social effects were largely negative. Social polarisation, pollution and the need to work ever harder depressed standards of living for most people in the sixteenth and seventeenth centuries.
\end{abstract}

\section{Introduction}

One of the fiercest and most productive historical debates - and one of the most ideology-laden - has been that on the transition from feudalism to capitalism. ${ }^{1}$ Although interest in this specific debate and its ideological implications seems to be waning now, the importance of reconstructing and explaining long-term changes in economy and society is still clear. Not only are many of us curious about the origins of modern economy and society, but a long-term analysis also offers us the opportunity to better investigate and understand the causes of structural changes in economy and society, the geographical differences these display, and their effects. This task becomes ever more urgent now that we have increasing insight into the different trajectories various parts of the world have taken, and are still taking, and now that we are becoming increasingly aware of the striking differences which have arisen over time between rich and poor parts of the world. This awareness has given rise, for instance, to the current debate on the Great 
Divergence and the causes of the differences in living standards between Europe and Asia. ${ }^{2}$ While some argue that these causes are located in the modern period, others would hold that their roots go back much further, perhaps even to the Middle Ages. This links up with the question of what role has been played by the differences in the organization of economy and society in these different parts of the world, and of the changes that have occurred within this organization, as well as with the transition to capitalism. ${ }^{3}$ Similar questions are also discussed within the debate on the emergence and effect of global power disparities, in which Wallerstein and others have attached critical importance to the rise of capitalism in Western Europe. ${ }^{4}$ These debates all point to the importance of a deeper understanding of the nature of capitalism, the chronology of its rise, and its early roots.

The Netherlands lends themselves well to such a search for the early roots of capitalism. The Netherlands stands out because of the early development of markets and market exchange, inducing some authors to even refer to this as the first modern economy. ${ }^{5}$ These same authors - De Vries and Van der Woude - surmised that the roots of this development are to be found in the late Middle Ages, and probably in the medieval institutions and structural conditions existing in the Netherlands, but they have deemed this, 'a terrain where quantification is useless [...] and tentative and suggestive treatments are as much as one can hope for'. This judgment has proved too pessimistic, however. In recent years, economic-historical, socio-institutional and archaeological research in the Netherlands has made strong progress in relation to the medieval period, allowing us to quantify developments better than before. The Netherlands also stands out because of the economic growth witnessed there in the pre-industrial era and the country's robust position within industry and especially trade, culminating in its leading economic position in the seventeenth century: the 'Golden Age'. Lastly, and related to

For their comments on previous versions of this article, I would like to thank Wim Blockmans, Chris Dyer, Klaas van Berkel, the participants in the ICHS preconference in The Hague (November 2008) and those in the History of Population and Social Structure seminar in Cambridge (March 2009).

Cf. T.H. Aston and C.H.E. Philpin (eds.), The Brenner Debate: Agrarian Class Structure and Economic Development in Pre-Industrial Europe (Cambridge 1985).

2 On this divergence: L. Pritchett, 'Divergence, Big Time', Journal of Economic Perspectives 11
(1997) 3-17, and F. Bourguignon and C. Morrison, 'Inequality among World Citizens, 1820-1992', American Economic Review 92 (2002) 727-744.

3 Cf. for instance P.H.H. Vries, 'Are Coal and Colonies Really Crucial?: Kenneth Pomeranz and the Great Divergence', Journal of World History 12:2 (2001) 407-446.

4 I. Wallerstein, The Modern World System (2 volumes, New York 1974, 1978).

5 J. de Vries and A.M. van der Woude, The First Modern Economy: Success, Failure, and Perseverance of the Dutch Economy, 1500-1815 (Cambridge 1997) 159-165. 
this, the Netherlands stands out because of the high level of urbanization. The urbanization rate increased from about 10 percent around 1300 (a rough estimate) to roughly $35-40$ percent for the Netherlands as a whole and no less than 50-6o percent for the western Netherlands by the end of the sixteenth century. At that time, this was the highest level in all of Europe, having surpassed the other highly urbanized parts: the southern Low Countries (Belgium) and the central north of Italy. This forms a clear indication of the high level of specialization, the availability of surpluses, and the importance of the secondary and tertiary sectors in the Netherlands in this period.

The latter can also be calculated more directly, at least for Holland (the westernmost area of the Netherlands). Extensive reports by government commissioners on economic conditions in Holland for the period around 1500 make it possible to reconstruct the distribution of labour input in the various sectors of the economy. ${ }^{6}$ In this reconstruction, in the countryside of Holland, only 40-45 percent of labour input went into agriculture; onefifth into fisheries; one-tenth into peat digging and groundwork (especially dyking); one-tenth into shipping, and one-tenth into textile production. In Holland as a whole (town and countryside), only 25 percent of labour was active in agriculture, supplying less than 20 percent of Gross Domestic Product (GDP). If fishing and peat digging are included, the primary sector still involved no more than 39 percent of labour, generating only 31 percent of GDP. Industry accounted for 39 percent of GDP, and services for 30 percent. In most other parts of Europe, this low share of the primary sector was reached only in the nineteenth century. Without making a claim for some type of Dutch exception, it is clear that these precocious developments make the Netherlands an interesting field for investigating the medieval roots of capitalism.

But what exactly is capitalism? The use of the term capitalism, or the phrase transition from feudalism to capitalism for that matter, is no longer self-evident; owing perhaps to the ideological charge associated with these. Instead, most historians now prefer to use rather vaguer notions, such as 'modernization' and 'rationalization', often portraying these processes as benevolent, almost necessary, lending their histories a teleological flavour. This lack of specificity hampers research. In particular, it makes it difficult to analyze and explain why these developments show such marked geographical differences, even between neighbouring areas. These differences existed even within a relatively small territory such as the Netherlands, as will become clear below. 
In order to allow for a real analysis, we will use what is perhaps a subjective and restricted, but nevertheless sharp, definition of the transition from feudalism to capitalism: namely the transformation of a society dominated by small, independent producers who had a strong grip on the means of production and whose produce was partly extracted by noneconomic force and/or exchanged by means other than the market, into a society in which there is a pronounced division between propertyless wageearners and entrepreneurs who own the means of production, and thus have a way to appropriate a surplus. In this situation, most of the exchange of goods - but also of land, labour and capital - is by way of the market, and the competition arising fosters a continuous drive for profit and the re-investment of these profits. This definition leads us to investigate a number of elements in order to analyse the transition to capitalism and to define its chronology. The main elements are the social distribution of property, the distribution and transfer of surpluses and the rise of markets for land, labour, capital and goods.

The rise of wage labour in particular is a principal element in the structural transformation of economy and society. The change from coerced labour and independent labour - dominant in most parts of Europe until the modern period - to wage labour forms perhaps the most fundamental element of the transition from medieval, feudal society into modern, capitalist society. This created a mass of people, often largely or fully proletarianized, who were legally free but dependent on the sale of their labour in the market, and thus subject to competition in the labour market, with the accompanying severe effects on their social and economic behaviour. Also, a large reservoir of wage labourers now came into being, available to agricultural and industrial entrepreneurs striving to expand their enterprises. These labourers, as well as other groups, no longer had direct access to the means of subsistence, requiring them to use the market for goods in order to acquire the necessities of life. Accumulation of the means of production, and the concomitant proletarianization, was also facilitated by the growing market exchange of land and capital and the ensuing competition within the market. This paper investigates to what extent, and how, these elements came into being in the Netherlands as early as the later Middle Ages.

In order to explain structural changes in this field, historians have often looked at such elements as the rise of trade, cities and markets and the monetization of the economy. In some definitions of this transition, these elements are presented as though they constitute the heart of the transition, while in others they are put forward as though they were at the least the driving forces behind it. This view seems particularly tempting in the case of the late medieval Netherlands, since this became the most urbanized part of Europe. In most of the older studies on structural changes in the economy and society, cities were almost automatically the focus of attention, following the traditional idea that these were the new, non-feudal islands in a rural 
feudal sea, where developments and changes occurred first. From the towns these changes radiated out over the surrounding countryside, the argument goes. However, it has recently become clear that this focus on the cities is no longer tenable, even for the highly urbanized Netherlands. This is partly the result of the reception of international literature nuancing the 'modernizing' role of towns, showing that these too could be an integral part of a feudal structure and did not always undergo a rapid transition, and of the literature on proto-industrialization and the agrarian roots of capitalism. These studies have made us aware of the fact that changes were at times even more rapid in the countryside than in the towns. Publications on proto-industrialization, for instance, suggest that capitalist relations of production often emerged earlier in rural industries than in many cities dominated by guilds and small commodity production. These ideas are increasingly incorporated in recent studies published on the transition to capitalism in the Netherlands, where full attention is paid to the countryside, and particularly to the interaction between town and country. ${ }^{7}$ An added element in the case of the Netherlands is the approach which highlights the regional character of these developments and the resulting regional diversity. ${ }^{8}$ This also opens up possibilities for comparative regional analysis.

This regional approach is even more suitable for the Netherlands than for some other parts of Western Europe, since the present-day Netherlands did not form a single state or principality during the period under investigation, but rather was covered by a large number of principalities, counties and independent lordships, which only slowly became incorporated into the Burgundian and later Habsburg empires, together with the southern parts of the Low Countries and other areas outside the present-day Netherlands. Even then retaining many of their administrative/legal differences and peculiarities. ${ }^{9}$ Economically, regional differences within the Netherlands were also pronounced, and these did not necessarily overlap with political boundaries. In the economic sphere, the regions interacted not only with each other but also - and ever more intensely - with other parts of Western and Northern Europe, most notably Flanders, Brabant and northern Germany. This interaction took place by way of the market for goods, but also the markets for capital and even labour. In this interaction, each region followed

A main example: P.C.M. Hoppenbrouwers and J.L. van Zanden (eds.), Peasants into Farmers?: The Transformation of Rural Economy and Society in the Low Countries (Middle Ages-19th Century) in the Light in the Brenner Debate (Turnhout 2001). Cf. also P. Brandon, "Marxism and the "Dutch Miracle". The Dutch Republic and the Transition Debate' (paper 2009).
8 This is a leading theme in: B.J.P. van Bavel, Manors and Markets: Economy and Society in the Low Countries, 500-1600 (Oxford 2010).

9 W.P. Blockmans and W. Prevenier, De Bourgondiërs. De Nederlanden op weg naar eenheid 1384-1530 (Amsterdam 2000). 


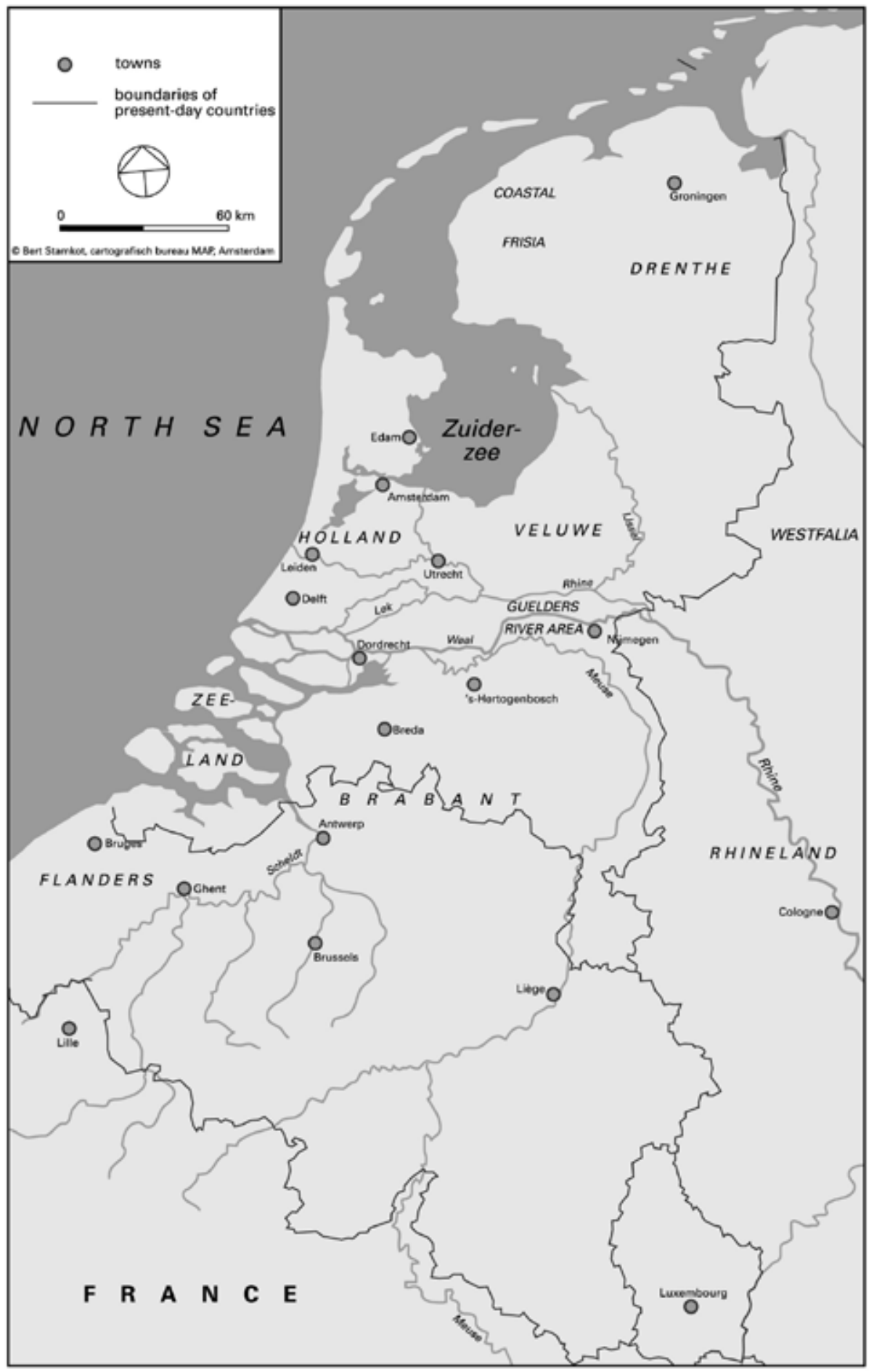

Map of the Low Countries in the late Middle

Ages, indicating the present-day boundaries of the Netherlands and Belgium and the main towns and regions discussed. 
its own distinctive, and sometimes complementary, path and as a result regional differences often became even more pronounced in the course of the later Middle Ages. Some attention will be paid to these regional differences, but the main focus will be on generalizations for the Netherlands as a whole and the specific experiences of certain prominent regions, namely those undergoing the most conspicuous development.

We will use the opportunities opened up by recent studies to investigate whether the transition to capitalism in the Netherlands started - or was even already evolving - in the late Middle Ages, and when and how exactly this happened. To this end, we will first reconstruct the chronology of the emergence of market exchange. In Section 3, we will then examine the process of proletarianization. In the following section (4), we will reconstruct geographical differences in these processes, both within the Netherlands and between the Netherlands and elsewhere. In order to at least partly explain these differences, we will look at the institutional organization of markets (Section 5). Lastly, we will look at the effects of these elements on the actual functioning of markets (6) and on economy and society more broadly (7).

\section{Chronological development of market exchange}

Recent investigations allow us to reconstruct the chronology of the emergence of markets in the medieval Netherlands fairly well. Seen within a European perspective, this emergence can be described as early. The crucial takeoff point of the market for goods and products was the eleventh/twelfth centuries, and that of the markets for land, lease, capital and labour the thirteenth/fourteenth centuries. In some regions, this development took on almost revolutionary forms, as with the breakthrough of the leasing of land for short, competitive rents in the Guelders River area. Here, the area leased out increased abruptly in the decades around $1300 .{ }^{10}$ Around the mid-fourteenth century, large landownership in the area was almost wholly given out in the form of short-term leases. In all respects, these leases already conformed to the definition of present-day short-term leases, with clear contractual, voluntary, economic characteristics. By the sixteenth century, more than half of the land in the Netherlands was leased out on a short-term basis, while the Netherlands also possessed a lively land market, resulting in high mobility in terms of both land ownership and the right of land use.

its Chronology and Causes', in: Idem and P.

Schofield (eds.), The Development of Leasehold in Northwestern Europe, 1200-1600 (Turnhout 2009) 179-213. of Short-Term Leasing in the Netherlands and

Other Parts of Northwestern Europe (11th-16th

Centuries): A Tentative Investigation into 


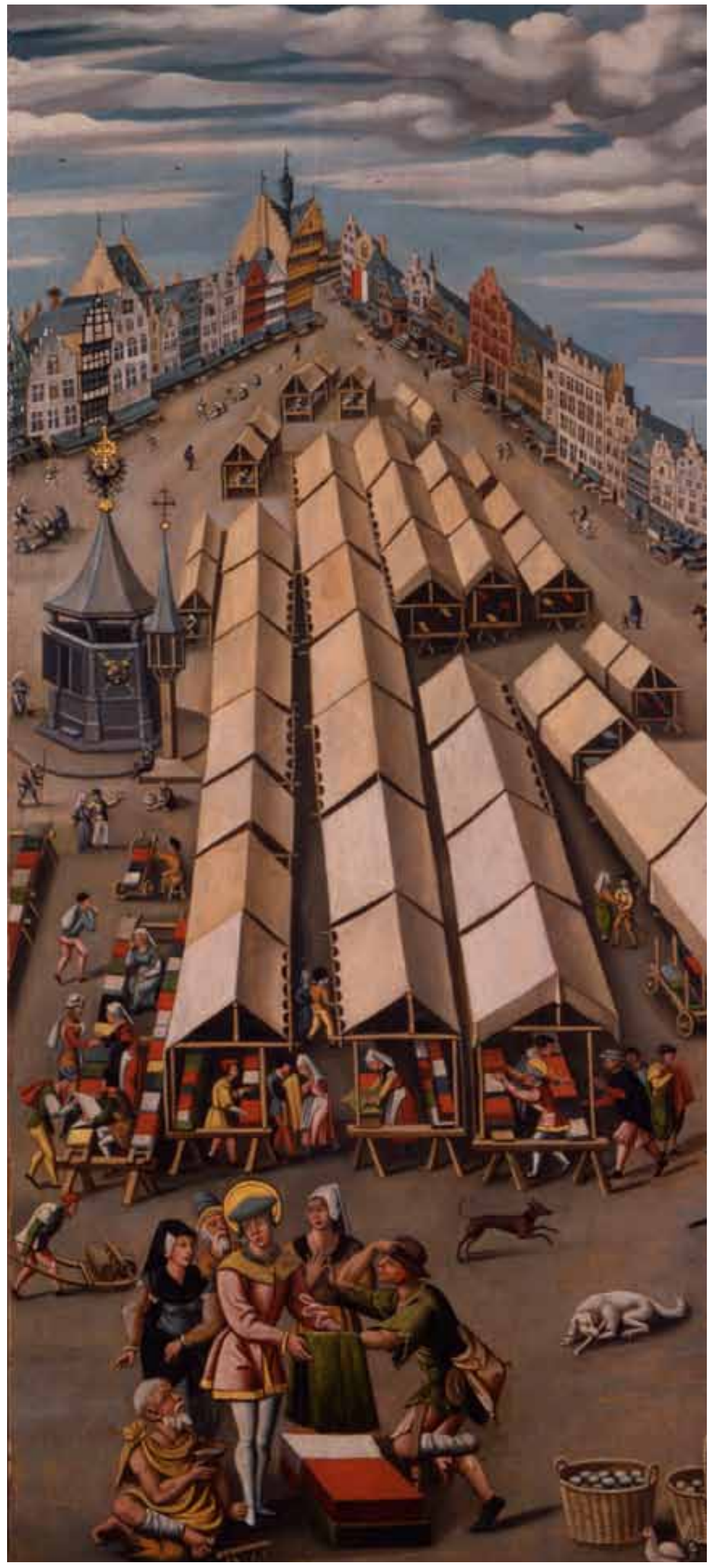


The rise of wage labour was more gradual, with the thirteenth and fourteenth centuries probably seeing an acceleration of this process. In the sixteenth century, about a third to half of all labour in the Netherlands was performed for wages; in the countryside of the Guelders River area even rising to almost 60 percent. ${ }^{11}$ Free, contractual wage labour became very substantial, particularly in the countryside and in the urban services sector. In regions such as the Guelders River area and Holland, wage relations were generally less personal than elsewhere, and sometimes even impersonal, partly owing to the wide recruitment area labourers were drawn from. Arrangements between employer and labourer were formal and based on the regular payment of a money wage, for instance on a daily, weekly or monthly basis.

Also, there was a well-developed capital market, which started to emerge in the thirteenth century and broke through all over the Netherlands in the fourteenth century. This capital market was not characterized by sophisticated instruments and highbrow financial techniques, as found in northern Italy and Flanders, but rather by a great number of small participants being able to obtain long-term credit at ever-lower interest rates. In the sixteenth century, the interest rate had reached 6 percent; a level not that dissimilar from the today's. A substantial share of households participated in this market; in Holland perhaps even more than half. ${ }^{12}$ There is some evidence of the volume of capital markets from fifteenth/ sixteenth-century Edam, a small town to the Northeast of Amsterdam. Its tax registers - which offer only a minimum figure - show that a considerable proportion of the households either owned or owed long-term debts. In Edam, the proportion fluctuated from at least a fifth to half, and in the surrounding countryside was about half of this. Short-term debts must have been even much more widespread. Markets for goods and products were also large. In the sixteenth century, most agricultural and industrial production was brought to market, and no longer consumed within the household or exchanged by mechanisms other than the market. Of the end-products of agriculture and industries in Holland, probably some 85-90 percent was

Anonymous, The Drapers' Market in 's-Hertogenbosch.

Noordbrabants Museum, 's-Hertogenbosch, around 1530.
11 B.J.P. van Bavel, 'Rural Wage Labour in the Sixteenth-Century Low Countries: An Assessment of the Importance and Nature of Wage Labour in the Countryside of Holland, Guelders and Flanders', Continuity \& Change 21:1 (2006) 37-72.

12 C.J. Zuijderduijn, Medieval Capital Markets: Markets for Renten, State Formation and Private Investment in Holland (1300-1550) (Leiden 2009) 232-247. 
destined for the market; these markets were found in Holland, in other parts of the Netherlands, but also in Flanders, Brabant, the Rhineland and even further afield. ${ }^{13}$

As early as the sixteenth century, in most parts of the Netherlands the exchange of land, labour, capital and goods by means of the market was far advanced or had already become dominant. This fundamental transition had evolved over a few centuries. During this relatively short period, the dominance of mostly self-sufficient, small-scale production and the combination of all kinds of unspecialized economic activities within the household, disappeared. Also the situation in which the exchange of land, labour and capital were firmly embedded in personal networks, with a strong role for relatives, neighbours, co-villagers and the local lord, now disappeared. In its place, a situation arose in which this exchange was mainly through the market; a change which had radical consequences. The main ones being the sharpening up of economic competition, which in its turn resulted in further specialization, ongoing investment and accumulation, but also in an increase of geographical mobility, social polarization and proletarianization.

\section{Processes of proletarianization}

The process of proletarianization took various forms. One of the main ones was found in the countryside, as peasant producers lost their rights to the main production factor, land, whether through loss of ownership rights, usage rights or other rights giving access to the fruits of the land. The growing transfer of these rights by way of the market played a major part in this. This facilitated both the fragmentation of family holdings into dwarf holdings by semi-proletarianized peasants and, at the other end of the social spectrum, the accumulation of land into large landholdings. A specific aspect of this was the buying up of peasant land by wealthy burghers, as happened in Holland in a most pronounced way. By 1560, some 30-35 percent of the land in Holland had already passed into the hands of burghers and urban institutions. In the following decades, the share of burghers rose even further, perhaps to some 50 percent of the total area in Holland by around $1600 .{ }^{14}$ An additional

the Countryside in Flanders and Holland', Revue Belge de Philologie et d'Histoire 81:2 (2003) 11571159.

14 B.J.P. van Bavel, 'Rural Development and Landownership in Holland, c. 1400-1650', in: O. Gelderblom (ed.), The Political Economy of the Dutch Republic (Aldershot 2009) 167-196. 
element in Holland was the subsidence of the peat soils, making a large part of the land unsuitable for the cultivation of grain and thus precluding access to subsistence. This can be seen as an ecological route to proletarianization, which closed off the possibility of subsistence farming and forced farmers into other agricultural and non-agricultural sectors, making them dependent upon the market for their input, for the marketing of their products and for obtaining an income from wage labour. ${ }^{15}$

Perhaps even more fundamental to the loss of access to land for producers was the accumulation of lease land. This process was mainly found in regions dominated by large landownership, such as the Guelders River area and the Frisian sea clay area. These had ample land available for lease, since by around 1400 almost all large landownership was already given out for short term leases, as we have observed above. Via a highly flexible and competitive lease market, this land could thus be freely accumulated by financially powerful farmer-entrepreneurs, benefiting from the socioeconomic circumstances and the relative decline of wages in this period of population growth. By using the possibilities for capital-intensive market specialization and reducing labour inputs, they further increased their profits and strengthened their position, gradually pushing aside small and mediumsized tenants. ${ }^{16}$ The result, especially combined with the population growth of the fifteenth and sixteenth centuries, was the emergence of an ever-larger semi-proletarianized and proletarianized rural population. Around the middle of the sixteenth century, perhaps half of the population in this area had no or little land at its disposal.

The division and privatization of commons, on the other hand, hardly played a role in the proletarianization of the rural population in the late medieval Netherlands. In Drenthe and the Campine, and other infertile regions where commons were important, common lands did retain their importance, and exploitation of the commons for market purposes was resisted. ${ }^{17}$ Relatively large sectors of the population retained access to land by way of their common usage rights. It was only in the eighteenth and nineteenth centuries that the division of commons really gained momentum here.

More important was the polarization resulting from protoindustrialization, with the proto-industrial peasants loosing their grip over land, raw materials and instruments. This dynamic process was not found in all proto-industrial regions. In inland Flanders, for instance, the

er, 'The Low Countries in the Transition to Capitalism', in: Hoppenbrouwers and Van Zanden (eds.), Peasants into Farmers?, 275-338, especially $310-315$.
16 B.J.P. van Bavel, 'Land, Lease and Agriculture: The Transition of the Rural Economy in the Dutch River Area from the Fourteenth to the Sixteenth Century', Past \& Present 172 (2001) 3-43.

17 J.L. van Zanden, 'The Paradox of the Marks', Agricultural History Review 47 (1999) 125-144. 
peasants retained their possession of the means of production, while urban merchants dominated the market; a situation displaying stability up to the eighteenth century. In the countryside of Holland, however, the situation was dynamic. The non-agricultural activities which emerged here - such as textile production, peat-digging, fowling, chalk-burning, bleaching, brick-making, fishing and shipping - often had a strong capital-intensive element, and this to an increasing extent. This went hand-in-hand with the growing dominance of urban investors in these sectors, as these made massive investments in fixed capital goods in the countryside, and with changes in the position of the labour force. ${ }^{18}$ In the thirteenth/fourteenth centuries, these activities were still mainly performed independently by peasant families who also exploited their own smallholdings, but during the course of the fifteenth and sixteenth centuries this was increasingly taken over by tens of thousands of semiproletarianized wage labourers.

A similar process of proletarianization was found in some urban industries and services. Again, this was mainly in those sectors which were capital-intensive and witnessed expansions of scale in the course of the period. This was most apparent in the brewing industry, in Holland and also in the towns in some other regions, in the fifteenth and sixteenth centuries. Total output from the breweries in the three major beer-producing towns in Holland rose from 30 million litres in 1400 to 100 million litres around 1570, mainly destined for export. Three-quarters of this quantity was produced by only 100 breweries in the city of Delft alone. Indicative of the increase in scale and rising labour productivity in this sector was also the fact that, in 1514, Holland had 377 breweries in the towns, employing some 10 workers each, whereas by the end of the sixteenth century there were 183 breweries with 16 workers each, producing the same volume or even more. ${ }^{19}$ In the course of this process, small-scale and rural brewing were extinguished.

It was not only possibilities for capital investment and technological innovation that played a role in this process, but also the weakness of the guilds in the towns of Holland. Elsewhere in the Netherlands, and even more so in the southern parts of the Low Countries, the guilds were more successful in combating increasing scale and protecting the vitality of independent small-scale production for the market. ${ }^{20}$ Still, even in Holland - where

Bavel, 'Early Proto-Industrialization', 1109-1165, and J.L. van Zanden, 'A Third Road to Capitalism: Proto-Industrialisation and the Moderate Nature of the Late Medieval Crisis in Flanders and Holland, 1350-1550', in: Hoppenbrouwers and Van Zanden, Peasants into Farmers?, 85-101.

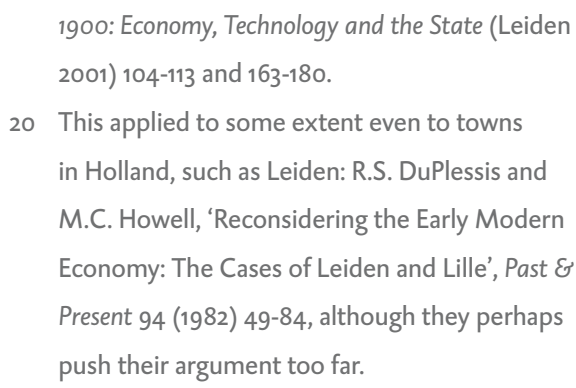


the guilds had scant influence - there was no shift to full-scale industrial capitalism. Large industrial factories did not emerge. The dominance of merchant interests in Holland and their advocacy of relatively free trade, and the state of technology which stood in the way of further big advantages in scale, prevented such a shift. ${ }^{21}$ As a result of these elements, and the additional role of the guilds in most towns outside Holland, the process of proletarianization was slowed down in most urban sectors. The progress of proletarianization in agriculture and in the countryside was at least as quick as in the towns, and probably even quicker. So, there were various roads to capitalism, and these roads were found particularly in the countryside, where the contours of a capitalist economy and society were becoming clearly visible in the Netherlands as early as the late Middle Ages.

\section{Geographical differences}

The preceding developments did not take the same form everywhere, nor take place to the same extent. On the contrary: geographical contrasts were sharp, even between neighbouring regions. Especially in regions such as the Guelders River area and coastal Frisia, the transition of the rural economy and society started early and evolved forcefully. This contrasts with the situation in the Veluwe (a region neighboring the Guelders River area), and in the Campine and Drenthe, where the labour market and the lease market in particular remained unimportant until far into the modern era, and where the process of proletarianization remained very limited.22 Such fundamental changes did not take place in the sandy inland regions in the eastern part of the country, such as Drenthe in particular. Apart from some intensification and minor increases in the degree of commercialization, in Drenthe the peasant structure remained largely intact; there was no structural transformation of the rural economy until the eighteenth century. ${ }^{23}$ On their small and medium-sized

the careful discussion by C. Lis and H. Soly,

'Different Paths of Development: Capitalism in

the Northern and Southern Netherlands during

the Late Middle Ages and the Early Modern

Period', Review 20 (1997) 211-242, especially 230-

236.

22

\section{'Transitie en economische ontwikkeling in de}

Nederlanden', Tijdschrift voor Sociale Geschiedenis

28 (2002) 147-174, especially 169-174, and Van

Bavel, Manors and Markets, chapter VI.
23 J.L. van Zanden, 'From Peasant Economy to Modern Market-Oriented Agriculture: The Transformation of the Rural Economy of the Eastern Netherlands, 1800-1914', Economic and Social History in the Netherlands 3 (1991) 37-59, especially 38-40, whereas J. Bieleman, 'De verscheidenheid van de landbouw op de Nederlandse zandgronden tijdens de "lange zestiende eeuw"', Bijdragen en Mededelingen betreffende de Geschiedenis der Nederlanden [BMGN] 105:4 (1990) 537-553, places greater stress on diversity and traces of development. 
farms, peasant families concentrated on the cultivation of grain and some small-scale livestock farming, mainly for their own subsistence. Long-term security and the needs of their own household were much more central to their production decisions than the market was.

Regional differences between towns were less pronounced than those between rural societies, although these did exist. Most marked were the differences between the towns in Holland, where the importance of market exchange and the degree of proletarianization made strong advances, and the towns in other parts of the Netherlands, where guild-protected, small-scale independent production remained much more important. These regions were not self-contained units: interaction did exist, and grew in importance in the late Middle Ages. The large towns - not necessarily situated in the regions themselves - were pivotal to the interaction between capitalist, proto-capitalist and pre-capitalist regions, and the flows of migrant labour, permanent migrants, agricultural goods, raw materials, semi-manufactured goods and capital between these. This interaction and exchange was found between regions within the Netherlands, but also with outside regions, including Flanders, Brabant, Rhineland and Westphalia, but also the Baltic, with trade hubs such as Bruges, Antwerp and Cologne playing a major role as platforms and facilitators of exchange. Rather than flattening out regional differences, however, in the course of the late medieval and early modern periods this exchange sharpened these differences and made the regions more complementary.

If we leave these regional distinctions behind, and look at the Netherlands as a whole, this area stands out within a European perspective. The rise of markets and the transition to capitalist relations was much earlier and more pronounced here than elsewhere. The decades around 1300 formed the crucial phase in this shift in relation to the rise of the markets for land, lease and capital; perhaps a little later also that for labour. The resulting polarization, accumulation and proletarianization took mainly place in the fifteenth and sixteenth centuries. Within Europe, these developments seem to have started earlier only in the centre and north of Italy, where they even accelerated during the thirteenth century, and perhaps also in East Anglia and Flanders. ${ }^{24}$ In these areas, however, these developments did not proceed

24 B.M.S. Campbell, 'Factor Markets in England before the Black Death', Continuity \& Change 24 (2009) 79-106, and B.J.P. van Bavel, 'Markets for Land, Labour and Capital between Town and Countryside, 12th-16th Centuries: Northern Italy and the Low Countries Compared', accepted by Journal of Interdisciplinary History. For the following on Norfolk: J. Whittle, The Development of Agrarian Capitalism: Land and Labour in Norfolk, 1440-1580 (Oxford 2000). 
further during the later Middle Ages, and in some respects even reverted from the fourteenth century on, with a strengthening of small-scale production and self-sufficiency, and/or growing importance of non-economic elements in exchange. ${ }^{25}$ Norfolk, as one of the most progressive agrarian regions of England, did have wage labour in the sixteenth century, but almost everyone still had access to some means of production (especially land). Also, many people in Norfolk had relations with the market, but only few were marketdependent. The contrast with areas such as Westphalia and other parts of Germany or most of France, where most of the population retained direct access to the most important factor, land, and where the exchange of land, labour and capital remained firmly embedded in social networks, such as family or kin groups and village communities, up to the eighteenth/ nineteenth century, is even greater.

These differences are even more apparent at a global level. The markets for labour and land in particular remained weak and small almost all over the globe, up to the nineteenth century. On the other hand, there was nothing unilinear or automatic in these developments and the differences displayed between areas in this respect. The case of Iraq, where markets for goods (and to a lesser extent for grain, land, labour and capital) did develop in the early Middle Ages ${ }^{26}$ - and much more so than in contemporary Western Europe - shows that projecting back modern differences would be a mistake. Iraq is another example of an area where this development did not proceed, but halted - in this case, especially after the tenth/eleventh centuries - and then reversed again. During the early modern period, Iraq had joined the other non-Western areas where markets were small and weak, such as India and Southeast Asia, but also highly-developed societies such as China and Japan. ${ }^{27}$ In the latter two countries, exchange by way of the market grew in importance during the early modern period, and in the eighteenth/nineteenth centuries, Japan even possessed well-developed, secure markets for land and capital ${ }^{28}$; the pace of this development was much slower than in the Netherlands, however, and the size of these markets remained modest.

E. Thoen, 'A "Commercial Survival Economy"

in Evolution: The Flemish Countryside and the

Transition to Capitalism (Middle Ages-19th

Century)', in: Van Zanden and Hoppenbrouwers,

Peasants into Farmers?, 102-149, and S.R. Epstein,

'Cities, Regions and the Late Medieval Crisis:

Sicily and Tuscany Compared', Past \& Present 130

(1991) 3-50, especially 14-15 and 36-43.

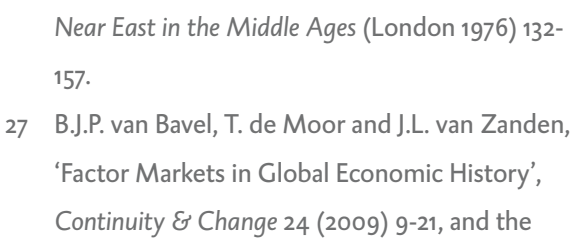


These geographical differences can be understood from the combined effect of push and pull factors. The push factors (proletarianization, dispossession and loss of access to land) have been described briefly above. From this short discussion, we can conclude that these processes were most pronounced in rural societies where elites held a firm position, expressed principally in rights to land, whereas at the same time they did not have - or had lost - the power to enslave or bind labor. Often, this relative position of the elites was built on the social structures that had already emerged in the early Middle Ages, during the period of occupation of the region in question. ${ }^{29}$ The same holds true for the fact that the processes of proletarianization could be mitigated, or even blocked, by a well-entrenched position on the part of the producers, through firm rights to the land and strong horizontal associations. Again, these elements are to a significant extent rooted in the early and high Middle Ages; path-dependency in this respect was pronounced.

The pull factors are mainly found in the attractiveness of market exchange, the security this offered and the opportunity to make profit, in comparison to the attractiveness of alternative systems of exchange for the social groups in question. Elites might be interested, for instance, in preserving a particular system of exchange that served its interests more than market exchange did. It was therefore not only economic, but also social factors that were decisive, within a process of continuous interaction. The nature and quality of the institutional framework of markets formed a crucial element in the outcome of this process. Guaranteed high quality offered security of market exchange, good accessibility of markets and low transaction costs, and prevented too many resources from being diverted into nonproductive endeavours, and made market exchange an ever more attractive option to ever more social groups. A favorable institutional framework was and is - therefore a necessary precondition for the growth of markets.

\section{Institutional organization of markets}

The institutional framework of the market for goods in the Netherlands had to a large extent already assumed its basic traits by the eleventh/twelfth centuries, during the first growth spurt of this market. This framework did not entail much in the way of market monopoly or staple force (the power to coerce commodity flows to one market), in contrast to the situation

\footnotetext{
28 O. Saito, 'Land, Labour and Market Forces in Tokugawa Japan', ibidem, 169-196.

29 This is a theme elaborated by Van Bavel, Manors and Markets, especially 387-397.
} 
developing in other centres of trade in Flanders and the north of Italy. Producers and traders were relatively free to choose between different markets. Only a few of the oldest towns, like Dordrecht and Groningen, succeeded in acquiring market dominance over their region, while Dordrecht also obtained some staple rights and trade privileges. But this was exceptional; generally speaking, people could choose from the many markets found in the numerous small towns, but also in some villages, where trading facilities such as weigh houses were also found..$^{30}$ In order to attract people, market places were keen on improving the institutional framework of trade and offering greater security for traders; actions taken by local authorities played a crucial role in this, as is most clearly seen in Holland. ${ }^{31}$ This resulted in a further extension and refinement of the formal institutional framework of trade. All of which does not mean that institutional barriers were absent altogether. Even in Holland, some privileges, trade barriers (consisting mainly of tolls, but also of sluices and other physical barriers in waterways) and differences in the degree of trade security, existed. ${ }^{32}$ Compared to other parts of Western Europe, however, the effect of these institutional barriers was minor.

The institutions of the labour market in the late medieval Netherlands offered great flexibility to both employer and labourer. Labour contracts in most regions, as in Holland and the Guelders River area, were mostly short and formal, consisting of verbal agreements for the day or one-year contracts without any further obligations after the end of the contract. This was in contrast to most of the surrounding regions in the southern Low Countries, as in inland Flanders, and in Germany, where the wage relationship was usually personal, informal and often based on a reciprocal exchange of services and capital goods. Also, in Holland and the Guelders River area, wage labour was relatively free. There were hardly any restrictions on the mobility of labour, no restrictions on wages, no fixed maximum wages, no indentured labour and no vestiges of manorial serfdom. ${ }^{33}$ This contrasts sharply with the situation in other parts of sixteenth-century Northwestern Europe, where these elements were much more prominent, as they were in many parts of England. The principal underlying cause of this was the high degree of personal, legal freedom existing in the Netherlands, which was already in place by the high Middle Ages. In some parts of the Netherlands, such as Drenthe and

$$
\text { and } 4 \text {. }
$$
Merchant Guilds in the Low Countries, 1250-1650', Jaarboek voor middeleeuwse geschiedenis 7 (2004) 199-238.

32 D. Aten, 'Als het gewelt comt...'. Politiek en economie in Holland benoorden het IJ, 1500-1800
(Hilversum 1995) especially 22-63, and also P.C.M. Hoppenbrouwers, 'Town and Country in Holland, 1300-1550', in: S.R. Epstein (ed.), Town and Country in Europe, 1300-1800 (Cambridge 2001) 54-79, especially 60-64 and 66-67.

E. Kuijpers, 'Labour Legislation at a Developing Labour Market. Holland 1350-16oo' (paper Utrecht 2008). 
parts of Frisia, the ordinary population had traditionally known relatively widespread freedoms. Even more apparent is the high degree of freedom enjoyed in those regions occupied only in the eleventh to thirteenth centuries, where the peasant-colonizers received their freedom straight away, and also firm property rights to their individual holdings, as well as the possibility of self-organization ${ }^{34}$; most clearly in Holland. Here, manorialism and a strong feudal nobility had been absent from the outset. This development was strengthened as territorial lords confirmed the rights and freedoms of both village communities and the emerging urban communities. As a result of the influence of these regions - but also of an existing balance between social groups - even some of the nearby regions, which were actually highly manorialized in the high Middle Ages (such as the Guelders River area) witnessed an early dissolution of this system, particularly in the thirteenth century. This widespread and early freedom of the ordinary population, being exceptional in a European perspective, formed the main precondition for the development of an open, free labour market.

In a similar vein, the emergence of more absolute, exclusive property rights to land formed the main institutional development allowing for the growth of land and lease markets, since these facilitated the transfer of ownership and rights of use by way of the market. This happened in a process in which overlapping claims by relatives, fellow villagers and lords disappeared as kinship ties weakened, manorialism dissolved and common lands were parcelled out. In their turn, these developments were promoted by the rise of land and lease markets within a process of mutual interaction. This process went fastest in regions such as Holland, where manorialism, the feudal system and common lands had been weak from the outset. In the central river area, the crucial phase in this process seems to have occurred in the thirteenth century, whereas in some regions - principally in the east witnessed these developments only much later, in the eighteenth-nineteenth centuries. In these peasant-dominated regions, security and self-sufficiency - as offered and protected by social networks and direct access to the means of subsistence - remained primordial, and this slowed down or even precluded such interaction.

One particular element in the development towards more absolute, exclusive property rights to land, and the security of these rights, as found in most of the Netherlands, needs to be highlighted: this is the role of public authorities. The protection of property rights to land by authorities was very strong here, at least from the fourteenth century onwards. This is clear from the security offered by public authorities against risk of confiscation 
by lords or other powerful entities, and the protection enjoyed by tenants and landlords against third parties encroaching on these rights. ${ }^{35}$ Also, registration of private land transfers before public rather than manorial or lordly courts started relatively early in Holland and Guelders River areas. Initially, from the fourteenth century onwards, this was done from the towns, but starting in the late fifteenth century, separate courts for rural districts started to produce such records. The parties engaged in transactions involving land - and also in the creation and selling of rents in the capital market increasingly preferred to have the transfer take place in a public court of justice, and to have it registered there, rather than doing so privately. This was mainly because of the greater legal security this offered with respect to third parties. ${ }^{36}$ The court books or protocols had legal force and evidentiary value.

In some parts of the Netherlands, the authorities even made seizure after sale before a public law court compulsory: sometimes on penalty of nullification of the sale. Also, the central authorities increasingly compelled local courts to register all deeds enacted, not so much because of the direct revenues involved, but owing to the fiscal interests of the government. Through these registers, the government was able to check the property returns of all taxable persons. The positive result was that information about land - and rents - was easily accessible from one central location. Moreover, all private or semi-public, rent-seeking parties were now banned from this field, in contrast to most parts of England and Germany, for instance, where lords played a much bigger role in registration, which also allowed them to levy fines on these transactions.

The above shows how the market institutions received their specific form in each locality and region, according to the socio-political context in which they were formed. They received this form according to the balance between different interest groups and the organizations that shaped the institutions, applied them and enforced their observance, either directly or through the state. In the late medieval Netherlands, and particularly in Holland, the role of the state and local governments was highly conducive to market exchange, as these increased security and offered transparency and protection of market transactions, for example by making judicial conveyance and registration of transactions in public registers compulsory, and by banning rent-seeking parties from this field. However, the role of authorities in the development of this institutional framework is not automatically

B.J.P. van Bavel, 'The Land Market in the North Sea Area in a Comparative Perspective, 13th-18th Centuries', in: S. Cavaciocchi (ed.), II mercato della terra secc. XIII-XVIII: Atti delle "Settimane di Studi" e altri convegni 35 (Prato 2003) 119-145, especially 129-132.
36 P.L. Nève, 'De overdracht van onroerend goed in de middeleeuwen', in: J.J. de Groot (ed.), De levering van onroerend goed. Vijf opstellen over de overdracht van onroerend goed vanaf het Romeinse Recht tot het Nieuw Burgerlijk Wetboek (Deventer 1985) 23-38. 


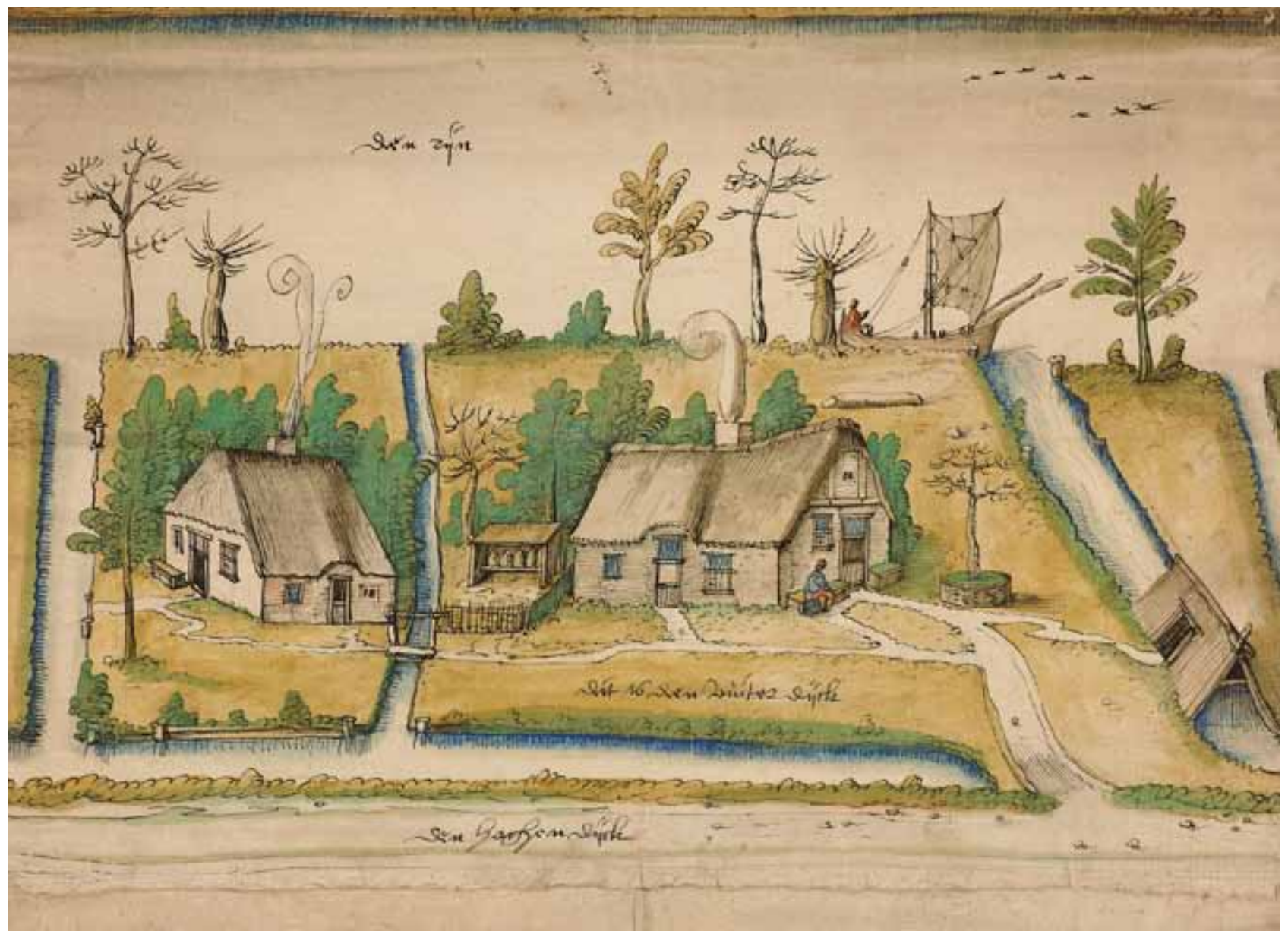

Two dwellings on the land outside the dike between the Oude Rijn and the Hoge Rijndijk, at Alphen. A shed with beehives can be seen between the dwellings. On the right is a shelter for boats.

Pieter Sluyter, Map of Estates of the Catharina Hospital in Alphen aan den Rijn, 1541 - 1545.

Regionaal Archief, Leiden. 
favourable to markets, nor geared towards promoting economic development. This role could also be a negative one, as is sometimes argued in the case of France and many other parts of Europe; but in the Netherlands, and especially in Holland, it turns out to have been mostly positive. This applies particularly to the role of authorities at local (village and city) level, but also at a regional or central level. The explanation for this exceptional situation appears to lie in the balance between different parties involved in political decision-making, with both political bodies and social groups precluding dominance by way of power and necessitating these parties to co-operate, or at least arrive at a rational compromise.

The deeper cause underlying all of the preceding elements was probably the exceptional balance between the social actors; a balance that did not allow one group to bend the institutions to its own interests at the expense of others. In late medieval Holland, and in the Netherlands in general, this balance was strong both within the elite - that is, between the rural nobility, patriciates and territorial lords - and within society as a whole, with peasants, village communities and urban craftsmen and entrepreneurs all holding a relatively solid position. The explanation of this exceptional balance seems to lie in the weakness of feudal elements in the Netherlands, the large degree of freedom enjoyed by the ordinary population and its high degree of self-organization. The decisive stage in these elements was the high Middle Ages, particularly in Holland, a region which only became occupied during this period. Holland was colonized by free peasants under a territorial lord, creating a situation of exceptional freedom with a nearabsence of non-economic compulsion, with the nobility gaining only a weak position - in contrast to most other parts of Western Europe. Here, and in most other parts of the Netherlands, the ordinary population also acquired ample scope for self-organization, both in town and countryside. This was expressed particularly in the formation of horizontal associations: village communities, commons, urban communes, guilds and religious and caritative organizations, such as parishes, alms-houses and hospitals, and also the water management boards. These were voluntary organizations, formed mainly by small-scale, independent producers who united and associated, often by way on an oath, and based on the consensus of all participants. ${ }^{37}$ These associations all emerged, or were formalized, in the eleventh-thirteenth centuries, and they gave the ordinary population the opportunity to pool resources and knowledge, and to make large investments, as well as allowing broad participation in political, economic and social decision-making.

in Europa (München 1996) 75-97, and P. Blickle, Kommunalismus. Skizzen einer gesellschaftlichen Organisationsform, volume ॥ (München 2000) especially 132-153. 
In the field of exchange, the associations fulfilled a role that could be complementary to that of the market, or could serve as an alternative by regulating and facilitating the exchange of land, labour and capital outside of the market. This role must have been important, although we hardly know how exactly these associations fulfilled it. In addition, the associations played a second role in the realm of exchange, be it inside the market or outside it: this was through combating the negative effects of exchange. These could be social excesses, such as sharp polarization or poverty - as combated by the guilds, the commons and the caritative organizations, but also ecological excesses, as in cases where intense commercial exploitation or profiteering threatened to result in exhaustion or pollution of natural resources. The commons, for instance, fought against over-grazing and erosion, and the water management boards to preserve dunes and dams, thus contributing to more sustainable development. Lastly, and equally importantly, these associations and other forms of self-organization offered a counterweight to elites in the formation of the institutional rules of market exchange. They lent otherwise powerless individuals the joint power to defend their interests. If necessary, this could even take the form of armed resistance, as the hundreds of noblemen who were killed by well-organized peasants in the marshes of Drenthe and Frisia experienced in a rather pointed manner. ${ }^{38}$

Associations thus contributed to the exceptional balance of social power in the late medieval Netherlands. Market institutions developed here in this favorable social setting and were not geared towards the rentseeking interests of a few particular groups; at least, not as much as in many other parts of Europe. As a result, they were conducive to market exchange, since they offered security and low transaction costs. This, however, is only a reasoned guess on the basis of a qualitative assessment. A next step would be to quantitatively measure the quality of the institutional framework of markets and the effects of this on the functioning of these markets.

\section{Quality and functioning of markets}

In a direct sense, this quality can only be measured in relation to the capital market. The level of interest rates in capital markets probably forms the most evident quantitative expression of the efficiency of the institutional framework. ${ }^{39}$ For the Netherlands, and particularly for Holland, there is

38 R. Köhn, 'Freiheit als Forderung und Ziel bäuerlichen Widerstandes, 11.-13. Jahrhundert', in: J. Fried (ed.), Die abendländische Freiheit vom 10. zum 14. Jahrhundert (Sigmaringen 1991) 325-387. Economic Performance (Cambridge 1991) 69 . 
ample evidence of a drastic fall in interest rates for long-term loans, from 10 percent in the fourteenth century to some 6-7 percent in the fifteenth century. ${ }^{40}$ The demographic catastrophe of the Plague, and the concomitant increase in the capital/people ratio, does not offer a satisfactory explanation for this drop, because Holland did not suffer great loss of life, and also because interest rates continued to fall as population numbers recovered and then rapidly increased in the sixteenth century. This in contrast to Italy, for instance, where interest rates started rising again. It seems that institutional improvements must principally account for the long-term developments in the Dutch capital market.

Apart from this indicator, we have to rely on indirect indicators of the quality of the institutional framework: the relative size of the markets, the integration of these markets - as these reflect the absence or presence of possible barriers, and the accessibility of the markets. These aspects have recently been investigated for late medieval Holland. ${ }^{41}$ The results obtained with reference to the size of these markets have been discussed above (Section 2). The share of land, labour and capital transferred by way of the market instead of other allocation mechanisms was much larger than in other parts of late medieval Europe. There also seems to have been a high level of integration of markets, as we can see from the interest rates in the capital markets in Holland. At the beginning of the sixteenth century, large towns, small towns and villages on average paid about the same interest on long-term debts: 6.3, 6.4 and 6.5 percent respectively. ${ }^{42}$ In the small town of Edam, we can observe another sign of market integration: when we look at interest rates, the spread around the mean was quite small (in 1514, 61 percent of long-term loans had the average interest rate of 5.6 percent; in 1563 this was 81 percent). ${ }^{43}$ Differences between town and countryside were also very modest: no more than a few tenths of a percentage point. Lastly, in late medieval Holland both public debt (low-risk government bonds) and private debt in the countryside was usually contracted against interest rates of between 5 and 6 percent. The small difference between these suggests that rural capital markets were already quite efficient. ${ }^{44}$

In the Utrecht research project 'The Rise,

Organisation and Institutional Development of Markets in Holland, 11th-16th Century', sponsored

by NWO and carried out in the period 20012007. Cf. also B.J.P. van Bavel et al., 'The Rise and Decline of the Holland Economy, 11th-17th

Centuries. A Test Case for an Institutional Approach' (paper Utrecht 2008).$$
43
$$

$$
\begin{aligned}
& \text { 15th-16th Centuries', in: T. Lambrecht and Ph. } \\
& \text { Schofield (eds.), Credit and the Rural Economy in } \\
& \text { North-Western Europe, c. 1200-c. } 1850 \text { (Turnhout } \\
& \text { 2009). } \\
& \text { T. de Moor, J.L. van Zanden and J. Zuijderduijn, } \\
& \text { 'Microcredit in Late Medieval Waterland. } \\
& \text { Households and the Efficiency of Capital } \\
& \text { Markets in Edam and De Zeevang (1462-1563)', } \\
& \text { in: S. Cavaciocchi (ed.), La famiglia nell'economia }
\end{aligned}
$$$$
\text { europea. Secc. XIII-XVIII (Firenze 2009) 651-668. }
$$ 
Markets for goods and products were also fairly well integrated and showed low volatility of prices. In the decades around 1400 , the variation coefficient of annual wheat prices in the Netherlands was only some 8 percent on average..$^{45}$ The correlation coefficient of annual average wheat prices between towns in the Netherlands at that time was already in the range of $0.75-0.9$ (given a maximum of 1.0). Crucial developments in this respect had probably already taken place before the sources allow us to measure integration and volatility, i.e. from the fourteenth century on. After this, further advances were limited. Also, grain price volatility was no less in the Netherlands than in the southern Low Countries or England, for instance, where grain markets also became highly integrated. Still, in one respect the Netherlands - and Holland in particular - stood out: it became a pivot for the international grain trade in Northwestern Europe from the late fourteenth century on, as witnessed by the high degrees of integration with markets all over Western and Northern Europe. A substantial part of this grain trade was carried out by Holland shippers and Holland ships; around 1500, some 600 of the 1,ooo ships recorded as passing the Sound toll and carrying Baltic grain came from this province. ${ }^{46}$ Related to this was a huge increase in the total tonnage and number of Holland ships, and the florescence of the Holland shipbuilding industry. In markets other than the grain market, integration increased mainly in the sixteenth century. The highly volatile market for peat shows a clear increase of market integration and dampening of price variations from about 1530 on: at a time when the variation coefficient of prices on the various Holland markets was only 14 percent on average. ${ }^{47}$ The fact that each peat trader had the option to choose from various urban markets in order to market his produce was crucial to this market integration.

In the labour markets, freedom and integration were relatively high in most parts of the Netherlands. This is reflected, for instance, in the small differences between nominal wages in town and countryside in the fifteenth and sixteenth centuries. ${ }^{48}$ In Italy, owing to restrictions on immigration and mobility, but also to bigger price differences in the cost of living, this range could amount to 100-200 percent for similar occupations/tasks. In the southern parts of the Low Countries, some restrictions on mobility existed and entrance into the urban wage market was not always easy for countrymen, but the situation was less severe than in Italy. In Flanders, this is reflected

44 De Moor, Van Zanden and Zuijderduijn, 'Microcredit'.

45 J. Dijkman, Medieval Market Institutions, chapter 8.

46 M. van Tielhof, De Hollandse graanhandel 14701570. Koren op de Amsterdamse molen (The Hague 1995) 98-110.
47 C. Cornelisse, Energiemarkten en energiehandel in
Holland in de late middeleeuwen (Hilversum 2008)
$215-219$.
48 Van Bavel, 'Markets for Land, Labour and Capital'. 
in an urban/rural wage difference of some 20-50 percent. In Holland, where restrictions were weakest, urban/countryside differences at this time was very small indeed (at 10-30 percent), or even absent altogether. During the earlier period, this small difference can be attributed in part to the small size of the towns in Holland, but this no longer applies to the sixteenth century, as several towns had then become quite large; the weakness of restrictions and obstacles in the labour market was more important.

The accessibility of markets to women was relatively high in the late medieval Netherlands. Foreigners, such as Guiccardini in 1567, who visited Holland and Zeeland, were struck by the economic independence of women and their activities, particularly in trade, but also in production. In fifteenth and sixteenth-century Leiden, the largest textile centre in Holland, hardly any explicit regulations against the activities of women existed, and a substantial number of women seem to have been active as entrepreneurs in this sector, albeit sometimes on a smaller scale. ${ }^{49}$ In the decades around 1400 , about a fifth of the drapers and cloth retailers in Leiden were female, showing that women had access to capital, skills and markets. Independent female masters can also be found among corn-mongers, tailors and bonnet-makers in the northern parts of the Low Countries, for instance. Despite this, and despite the near absence of formal restrictions, in practice there was often an implicit division of labour between the sexes, even in Holland. And the same situation can be found with respect to remuneration in the labour market. Wages of men and women seem to have been fairly equal, although data are very scarce. In most cases, men and women performed different tasks and possessed different physical strength: factors which make it difficult to compare men's and women's wages. However, some exceptional seventeenth-century data on piece wages for yarn show that men and women were remunerated equally. ${ }^{50}$ At the same time, these labour markets remained segmented, and men occupied the best-paid segments of the spinning sector, as well as the textile sector more generally, while women occupied the lesser-paid segments. The degree of equality between the sexes in the labour market must therefore be qualified, but was probably greater than elsewhere in Europe.

There is ample evidence suggesting that capital markets were accessible to large parts of the population, including women. For instance, in Edam we encounter many households of modest means that participated in the capital market. Also, we encounter many women among the creditors and debtors; they formed about a quarter of the people active in the capital

M.C. Howell, Women, Production, and Patriarchy in Late Medieval Cities (Chicago 1986) 70-94, and E. Kloek, 'Vrouwenarbeid aan banden gelegd? De arbeidsdeling naar sekse volgens de keurboeken van de oude draperie van Leiden, ca. 1380-1580',
Tijdschrift voor Sociale Geschiedenis 13 (1987) 373-

402, although with different nuances.

50

E. van Nederveen Meerkerk, De draad in eigen

handen (Amsterdam 2006) 280-297. 


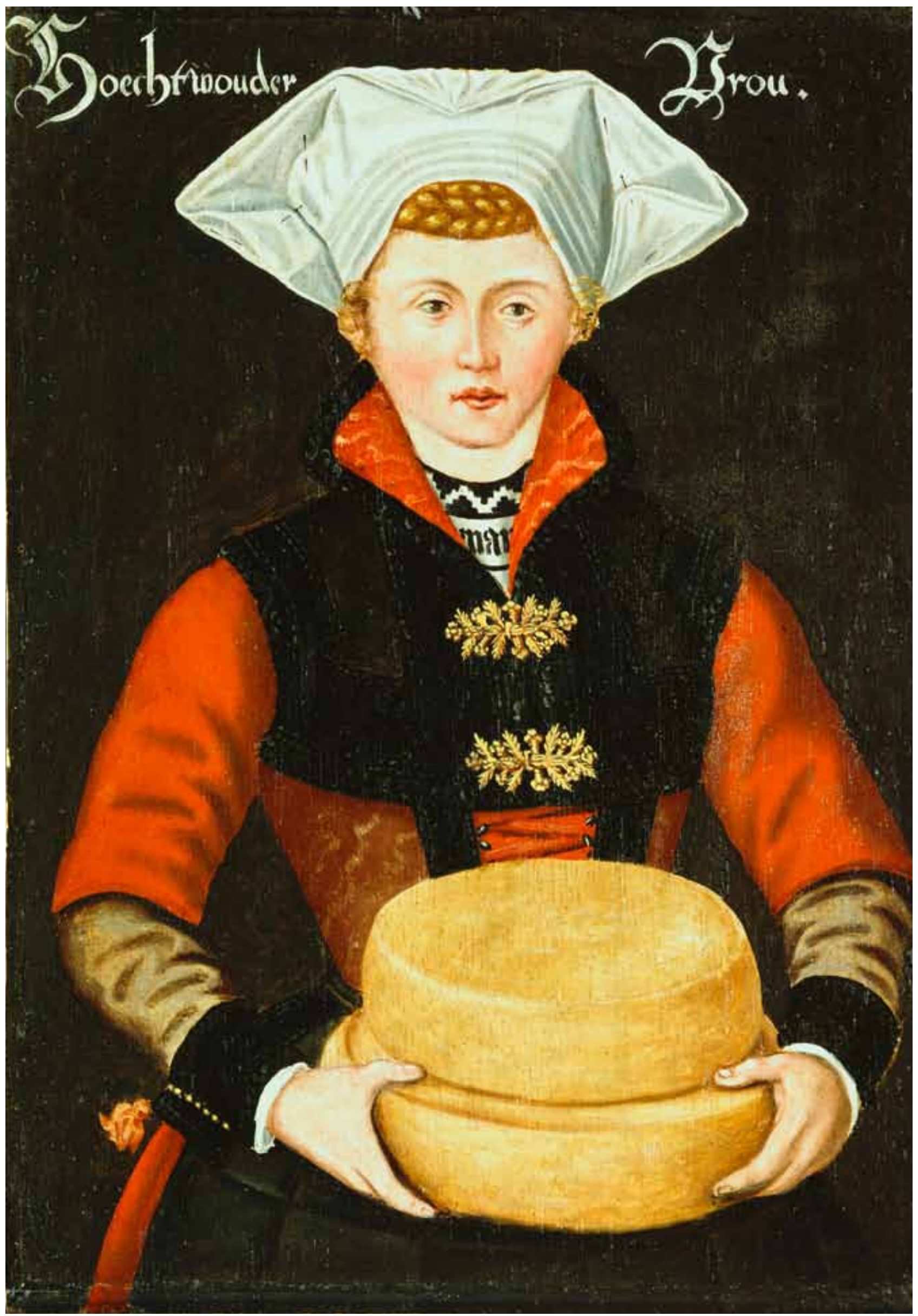


market..$^{51}$ Even when we take into account that some of the long-term debts may have changed hands over time, through bequeathing, endowing or resale, this shows that accessibility was rather high.

Another indicator for the accessibility of markets is the skill premium: the difference in wages paid to skilled and unskilled labourers in the same sector. In most of the Netherlands, this skill premium was low, suggesting that the acquisition of skills and entrance into the skilled professions was relatively easy. The skill premium in Holland was probably the lowest in all of Western Europe..$^{52}$ Calculations of the skill premium by comparing wages of hodmen/ labourers with those of craftsmen in the same sector show this exceptional position of Holland. In Antwerp, Bruges and Nijmegen, the skill premium around 1500 appears to have been fairly high, at 65-80 percent, whereas in Holland this was only 25-50 percent. For the earlier period, this low skill premium in the towns of Holland can in part be attributed to their small size and low demand for highly skilled, specialized labour, although this does not apply in the period around 1500, as these towns were then rapidly expanding in size. The explanation for the low skill premium should, therefore, rather be sought in the openness and flexibility of the labour market.

Although institutional barriers certainly existed, the institutional framework of markets in Holland - and the Netherlands more generally - seems to have been favorable, as the above data show. This precluded rent-seeking through markets, and allowed for reductions in both the cost of searches and information and the cost of protecting property rights and contracting. These low transaction costs, coupled with the high level of confidence in market transactions, induced more people to engage in the market. This allowed for a high volume of markets, high mobility of land, labour, capital and goods, and resulted in low wage differences, prices and interest rates. Often, this is enough for historians to conclude that the effect of this on the economy and society must have been beneficial: but was it? In order to assess this, we will look at the long-term effects of the rise of competitive markets and capitalist relations, especially in those parts of the Netherlands where their rise was most pronounced.

Anonymous, Woman from Hoogwoud Holding

Two Cheeses, before 1572.

Rijksmuseum, Amsterdam.
51 Zuijderduijn, Medieval Capital Markets, 236-241, and De Moor, Van Zanden and Zuijderduijn, 'Microcredit'.

52 J.L. van Zanden, The Long Road to the Industrial Revolution: The European Economy in a Global Perspective, 1000-1800 (Leiden, Boston 2009) 149171, and Van Bavel, Manors and Markets, 214-215. 


\section{Social and economic effects}

Did the emergence of the market and of market competition really stimulate economic growth and a structural increase in standards of living? And, if such a rise did take place during this period, were markets really the determining factor in this? Questions such as these have proved hard to answer, causing historians to make guesses concerning the development of growth and welfare during the later Middle Ages. These guesses have been directed mostly by qualitative indications, such as the flourishing of the arts and sciences in the seventeenth century, the period of the Dutch Golden Age. The final judgment about developments during the period from the thirteenth to the seventeenth centuries has therefore been generally positive, since these developments culminated in this cultural blossoming. Recent investigations, however, have made far more quantitative indicators available. When we distribute these data over the period 1000-1300 (during which the market still played a minor role in the allocation and exchange of land, labour, capital and goods), and the period $1300-1600$ (in which market exchange became dominant), this gives a mixed result. Much of the growth and positive development appears to have occurred in the Netherlands before 1300, that is: before the rise of the market.

GDP per capita in this period is hard to estimate. The best guesstimates currently available show that GDP per capita did increase a little over the period between 1000 and 1600 , but not dramatically. The level of GDP per capita in the late medieval Netherlands was higher than elsewhere in Europe, with the exception of Italy ${ }^{53}$, but this would probably already have been the case in the high Middle Ages. On the positive side, in contrast to other parts of Europe, GDP per capita in the Netherlands did not decline in the period of rapid population growth in the fifteenth and sixteenth centuries. This absence of decline was not only the result of Smithian growth owing to intensification of labour and specialization alone. Several parts of the Netherlands developed a highly capital-intensive industry and/or agriculture. Often, the large investments in expensive implements, land improvements, hydraulic or industrial works and other capital goods went hand-in-hand with a reduction of labour input, thus resulting in higher profits/surpluses and a rise in labour productivity. Most of these gains were eaten away again by population growth, however, although some remained.

Nevertheless, no spectacular rise of GDP per capita took place, but rather the retention of a level that was already fairly high before. Alongside

\footnotetext{
1400-1800 (London 2001) 69-87. The figures produced by A. Maddison, The World Economy; A Millennial Perspective (Paris 2001), are highly speculative and based on indirect indicators, with a very ambiguous relation to GDP per capita.
} 
this, a negative element seen in the late medieval Netherlands was a much sharper social polarization than in other parts of Europe, resulting from the fierce competition in the markets. This polarization was found especially in those towns and regions where market exchange was most dominant. Ever sharper differences between rich and poor could be encountered in the booming centers. This can be observed, for instance, in the industrial center of Leiden, where in 1498 the poorest 60 percent of the population owned only 3 percent of total wealth. ${ }^{54}$ Polarization was even sharper in sixteenth/ seventeenth-century Amsterdam. In 1630, a third of the taxed wealth in this metropolis was in the hands of the richest 1 percent. The Gini coefficient (a measure of inequality, with o.o indicating full equality and 1.0 full inequality) in 1585 was around 0.74 , but in 1630 it had already increased to 0.85 : one of the highest figures in pre-industrial Europe, comparable to the level in fourteenth/fifteenth-century Florence. ${ }^{55} \mathrm{~A}$ large share of the people in seventeenth-century Amsterdam had become totally pauperized. The splendour of the Dutch Golden Age to a large extent was at the expense of the lower middle classes and the upper lower classes, who sank to ever poorer substrata.

Even if GDP per capita had grown a little over this period, this social polarization means this would not have resulted in any increase in the purchasing power of the average person. In fact, there was probably even a decline in this. Industrial workers and construction workers around 1600 had lower real wages than their counterparts in the thirteenth century, the first period for which wage and price data are available. ${ }^{56}$ Even around 1345 - at the peak of pre-Plague population pressure - real wages of labourers in Holland had been higher than they were in the sixteenth century. ${ }^{57}$ In the course of the sixteenth century, on the threshold of the Golden Age, real wages fell even further, while working hours for obtaining these daily wages became longer. Moreover, many of the growing number of wage labourers were not fully employed, and this further reduced their income; institutional charity helped to relieve only some of the problems of unemployment, sickness and inability to work.

54 N.W. Posthumus, De geschiedenis van de Leidsche lakenindustrie, volume I (The Hague 1908) 386399.

\section{A Historical Comparative Study (Cambridge} 1987) 204-206, and J.L. van Zanden, 'Tracing the Beginning of the Kuznets Curve. Western Europe during the Early Modern Period', Economic History Review 48 (1995) 643-664.
56 Cf. also the calculations for England, with its much better sources for the earliest period: $G$. Clark, 'The Condition of the Working Class in England, 1209-2004', Journal of Political Economy 113 (2005) 1307-1340.

57 B.J.P. van Bavel and J.L. van Zanden, 'The JumpStart of the Holland Economy during the LateMedieval Crisis, c. 1350-c.1500', The Economic History Review 57 (2004) 510-516. 
These indicators are all fairly abstract, and do not tell the whole story about the welfare of the people. Even if real wages increased during the period 1300-1600, which as we have seen is highly doubtful, this need not have led to a rise in standards of living, since these were also affected by changes in the environment, pollution, living conditions, employment opportunities, leisure time and the access to sources of food and services outside the market. And, in the Netherlands, these elements did not develop favourably during this period: on the contrary.

We can obtain a sharper insight into the development of welfare thanks to the recent results of archaeological investigations into bones and dental remains. These allow us to get a better idea of average life expectancy. Syntheses are unfortunately still lacking, but the scattered data allow us to surmise that life expectancy in the medieval period fluctuated heavily, but did not undergo fundamental changes in the long term. For those who reached the age of twelve years old, life expectancy in the Netherlands around 1400 was approx. 38 years for men and approx. 31 years for women, although the wealthy lived much longer. In the early Middle Ages, the data show an average life expectancy for both men and women of c. 37 years..$^{58}$ This period therefore shows more of a decline than an increase.

Probably the best indicator of modal welfare, however, is the development of average human stature, since this is determined by quality of diet, diseases and environmental conditions; that is, by the main components of welfare. ${ }^{59}$ Again, research into bones has brought our insight much further. The archaeological data show a clear decrease in stature over the period 1000-160o, and an even clearer decrease over the longer period 600-180o. In the Netherlands, the average height of men in the early Middle Ages was 1.73/1.74 metres, declining to 1.71 in the thirteenth/fourteenth centuries, and to 1.69 in the fifteenth/sixteenth centuries. This low level remained throughout the seventeenth and eighteenth centuries, reaching its lowest point in the first half of the nineteenth century, at $1.67 .{ }^{60}$ Causes for this decline were growing pollution and the destruction of the environment as a result of its ever more intensive use, the packing together of people in towns and the increasing incidence of disease resulting from population growth and urbanization, and the ever less varied diet of the majority of people, as a result of growing population pressure and social polarization. progress can be made in the coming years.

A general introduction is offered by R.H.

Steckel, 'Strategic Ideas in the Rise of the New Anthropometric History and their Implications for Interdisciplinary Research', Journal of Economic

History 58 (1998) 803-821.

60 G. Maat, 'Two Millennia of Male Stature

Development', International Journal of

Osteoarchaeology 15 (2005) 276-290, and Van

Bavel, Manors and Markets, $145-148$ and 378. 


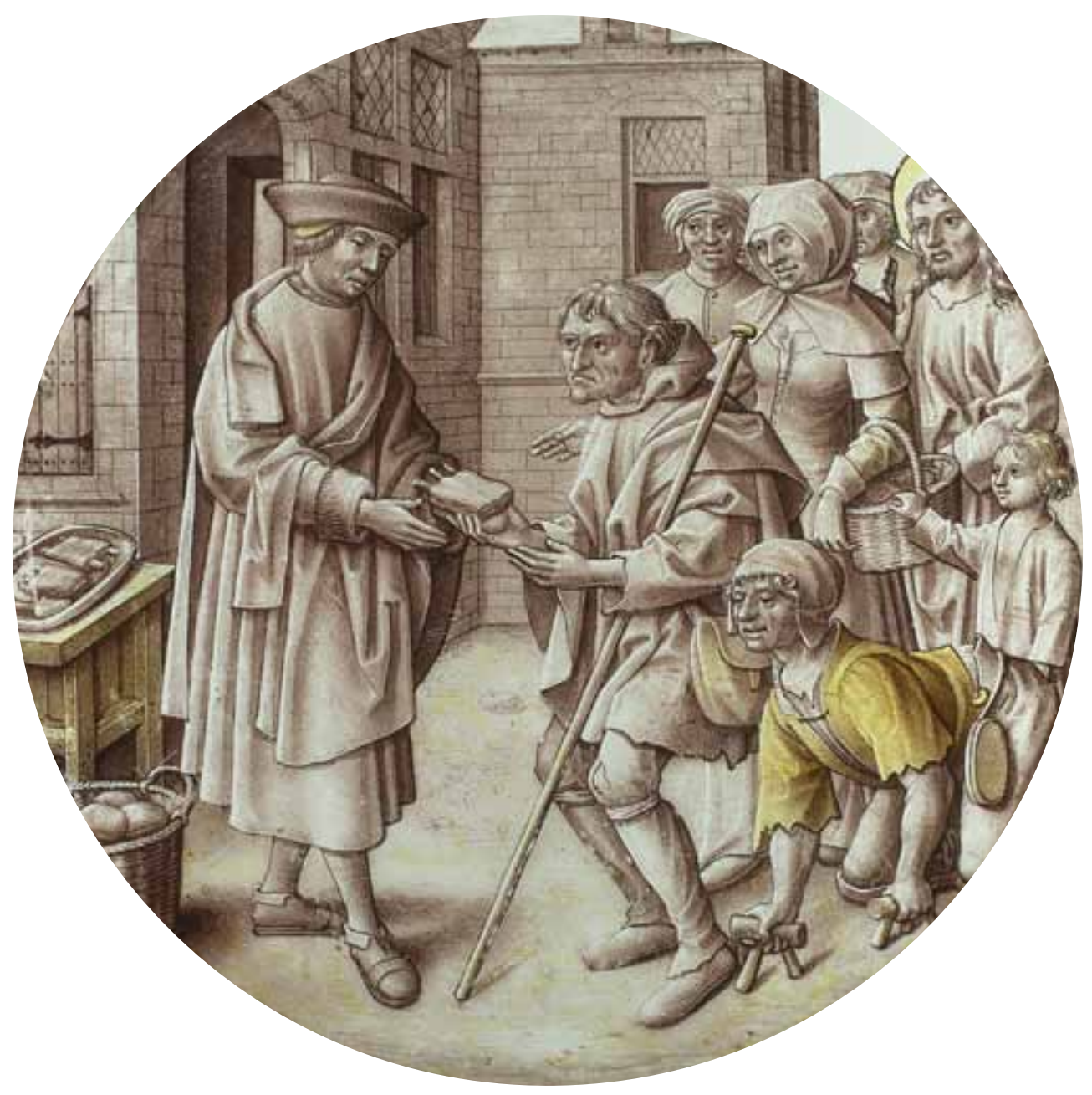

$k$
$z$
0
$\mathbb{2}$
$\stackrel{m}{m}$

75

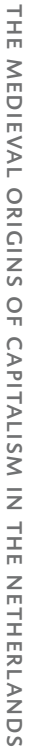

Sharing out food to the hungry. Standing in front of his house, the benefactor, warmly dressed in a coat with fur-trimmed sleeves, doles out food to a group of hungry people. In the group, to the right and somewhat in the background, Christ makes a gesture of blessing. Anonymous, sixteenth century.

Rijksmuseum, Amsterdam. 
We can conclude from the above that developments in the Netherlands over the period 1300-1600 do not constitute a clear success story. Apparently, the growth of markets did not always have a positive result. ${ }^{61}$ This even applies to the Netherlands, which often is considered the paragon of success in this period, owing to the rise of Amsterdam as a trading centre, the Baltic trade, the success of export industries and the start of Dutch maritime dominance. However, apart from mostly abstract indicators such as a growing urbanization rate, GDP per capita, interest rates and market sizes - indicators which do not intrinsically reflect enhanced welfare of the people - there was a decline in modal purchasing power and a decline in standards of living. In the period 1300-1600, in which markets became a dominant factor in the Netherlands, ever more people were poor, lived in filthy conditions, were malnourished and small. The occurrence of poverty and misery in the Dutch Golden Age - and especially in Holland - has been noted before ${ }^{62}$, but the data above show how general this misery was and how negative the comparison to the preceding centuries. Those who lived in parts of sixteenth-century Western Europe where the market was less developed, such as in Westphalia (but also in inland parts of the Netherlands such as Drenthe), were probably better off in terms of standard of living. ${ }^{63}$ Even if GDP/capita was not higher there, the negative effects of market competition and polarization were less present, and there was less population pressure, alleviating related problems such as pollution and diseases.

A last effect of growing market competition to be highlighted here is its effect on institutional development. The emergence of open and flexible markets favoured the position of merchants, who accumulated ever more capital, especially in the sixteenth-seventeenth centuries. As a result of this, public bodies became increasingly dependent on the financial resources of the merchant elites, especially those of trade metropolis Amsterdam, who gradually strengthened their grip over government and society. At the same time, the associations of independent producers were eroded by the processes of proletarianization and social polarization. The associations lost influence or were marginalized, or became dominated by elite groups. ${ }^{64}$ This undermined a Golden Age: Popular Culture, Religion and Society in Seventeenth-Century Holland (Cambridge 1991) 3-12 and 44-66.

63 J.L. van Zanden and L. Noordegraaf, 'Early Modern Economic Growth and the Standard of
Living: Did Labor Benefit from Holland's Golden Age?', in: C.A. Davids and J. Lucassen (eds.), A Miracle Mirrored (Cambridge 1995) 410-437.

64 Analyzed in an exemplary way for coastal Flanders by T. Soens, 'Polders zonder poldermodel? Een onderzoek naar de rol van inspraak en overleg in de waterstaat van de laatmiddeleeuwse Vlaamse kustvlakte (12501600)', Tijdschrift voor Sociale en Economische Geschiedenis 3 (2006) 3-36. 
their contribution to social balance. The group that benefited most from the extant organization of exchange - in the Netherlands, the merchant elite of the Holland towns - now gradually acquired a dominant position in society. As a result, the existing institutional organization of exchange, which apparently served the interests of this group best, became frozen at this point, because this dominant merchant group increasingly invested in retaining this framework, even if it was no longer conducive to growth in the face of changing economic conditions. The institutional framework was not adapted anymore to changing economic or ecological conditions. This led to stagnation and the relative decline of the area in question, as can indeed be observed in the case of Holland/the Dutch Republic in the course of the seventeenth century.

This investigation into the medieval roots of capitalism in the Netherlands thus yields a paradoxical result. On the one hand, we find a favorable institutional framework for markets, high mobility of land, labour, capital and goods by way of the market, high flexibility and freedom, and an early transition to capitalism. On the other hand, the effects on the economy were mixed, or slightly positive at best, while there was a negative effect on welfare. This can hardly be called a success story. Successful development rather seems to be found in a much earlier period, the eleventh-thirteenth centuries, as economic growth and drastic growth of population numbers were paired to a relatively high level of welfare. In various parts of the Netherlands, economy and society had already developed strongly before 1300 : in population growth and urbanization, GDP per capita, and standards of living. This favourable situation was reached at a period in which the market for goods had only just emerged, the market for land had only just started to emerge and the markets for lease, capital and labour had not emerged yet at all. Allocation and exchange through the market had barely developed yet; apart, to some extent, from the market for goods.

These findings show, or at least lead us to surmise, that the key to this socio-economic success is not primarily to be found in the market, but in the organizations which were formed in the period before 1300 . This may force us to look closer at the horizontal associations which were formed and formalized here in massive numbers in the eleventh to thirteenth centuries and assumed such a prominent role in social-economic traffic. Their role in enhancing or protecting welfare in this period deserves further investigation. Perhaps their role is mirrored by developments in the modern era. After the decline in the early modern period, general welfare and living standards in the Netherlands only started to rise substantially and structurally from late in the nineteenth century onwards. At the same time, co-operations, trade unions, political organizations and other horizontal associations - directly and indirectly, by way of their influence on the state - started to assume a bigger role in the exchange of labour, capital and goods, and more generally in the economy and society as a whole. 


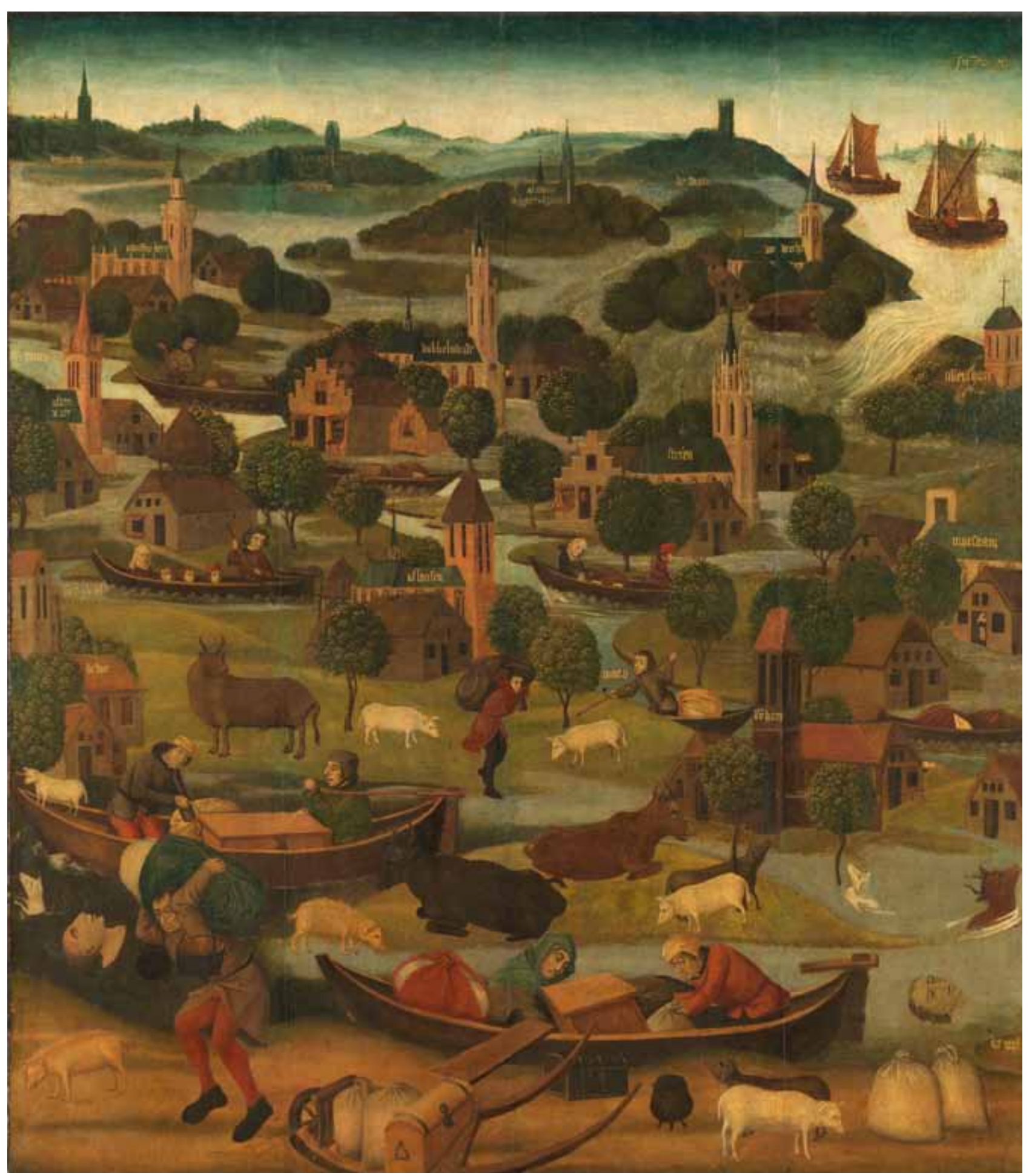


The results described above can bring us further in uncovering the causes of the geographical differences between rich and poor in the world today, and the role of capitalism in this divergence. Firstly, because it helps us to a better understanding of the chronology of the rise of markets and the transition to capitalism. In the Netherlands, and perhaps in some other regions surrounding the North Sea, capitalism was really rooted in the Middle Ages: not only in its institutional foundations, but also in its actual growth. This development therefore preceded the appearance of the Dutch Republic on the world stage as a global maritime power. Secondly, the above helps to qualify the effects of the rise of capitalism. Its rise in the Netherlands did contribute to capital accumulation, which probably took on forms greater than elsewhere in the world and facilitated the growing power of the Dutch Republic, but its effect on economic growth was modest at best, and its effect on living standards appears to have been a negative one. The history of the Netherlands, being the most prominent showcase of an early transition to capitalism, thus also offers some elements which contradict overly simplistic assumptions about the beneficial long-term effects of market competition.

Bas (B.J.P.) van Bavel (1964) is Professor of the Economic and Social History of the Middle Ages at Utrecht University. Field of research: Long-term changes in economy and society. Three recent publications: 1. Manors and Markets: Economy and Society in the Low Countries, 500-1600 (Oxford 2010); 2. 'The Organization and Rise of Land and Lease Markets in Northwestern Europe and Italy, c. 1000-1800', Continuity \& Change 23 (Cambridge 2008) 13-53; 3. 'The Transition in the Low Countries: Wage Labour as an Indicator of the Rise of Capitalism in the Countryside, 14th-17th Centuries', in: P. Coss, C. Dyer and C. Wickham (eds.), Rodney Hilton's Middle Ages (Past \& Present Supplement 2; Oxford 2007) 286-303.

In the night of 19 November 1421 (Saint

Elisabeth), a storm surge hit the coast of the

Netherlands. The dike was breached near the village of Wieldrecht, the polder flooded and dozens of villages disappeared beneath the water. The survivors from Wieldrecht moved to neighbouring Dordrecht, where they were given their own altar in Dordrecht Minster, for which, half a century later, panels were made depicting the disaster.

Master of the St. Elisabeth Panels, The Saint Elisabeth's Day Flood on 18-19 November 1421, around 1470.

Rijksmuseum, Amsterdam. 


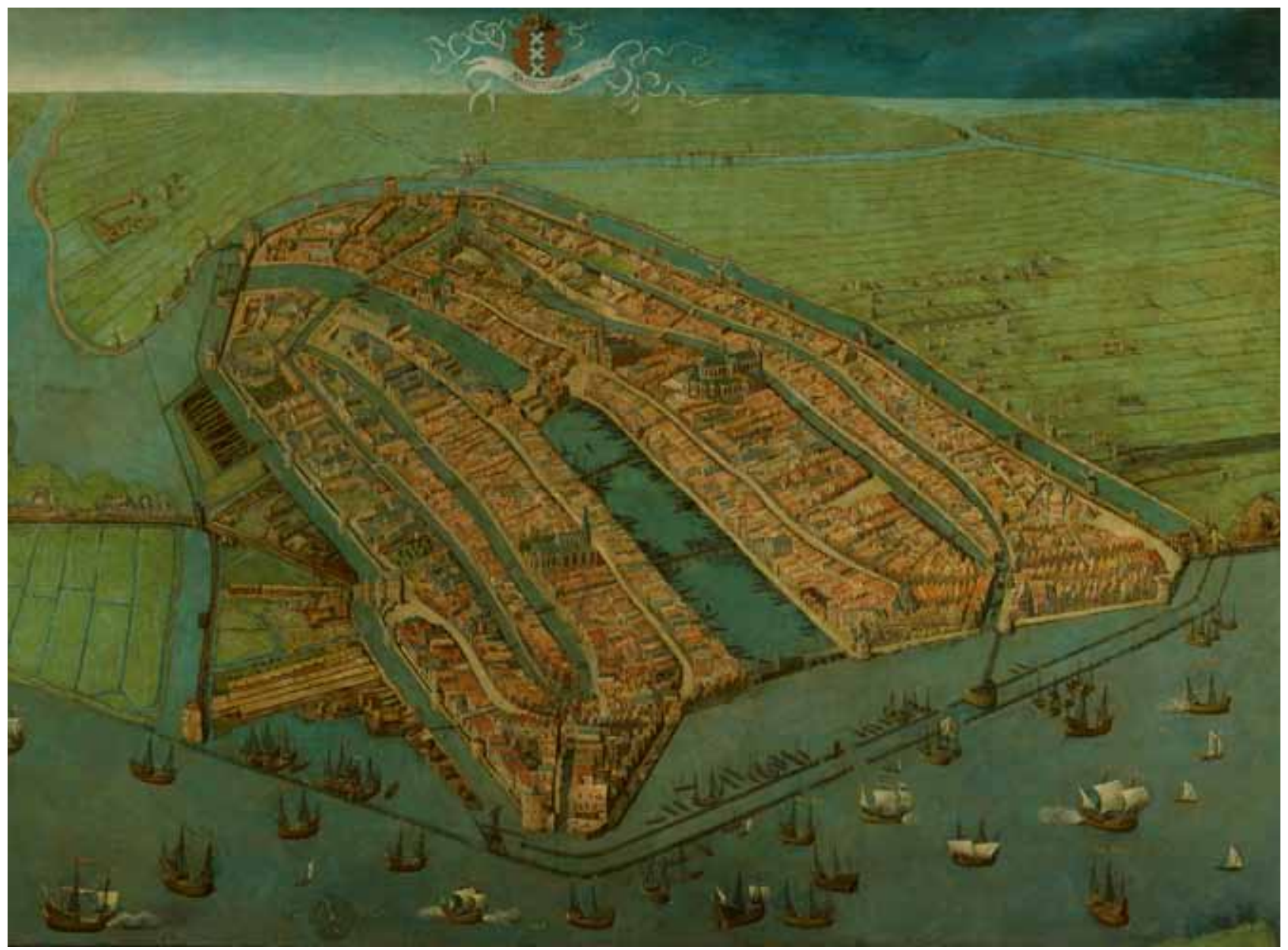

Cornelis Anthoniesz., Bird's Eye View of

Amsterdam, 1538.

Amsterdams Historisch Museum. 


\title{
The Dutch Republic. Laboratory of the Scientific Revolution
}

\author{
KLAAS VAN BERKEL | UNIVERSITY OF GRONINGEN
}

Historians agree about the significance of the Scientific Revolution for the development of modern society; there is little agreement, however, as to the nature and the causes of this major shift in our perception of the natural world. In this article, it is argued that we may profit from studying this problem in the context of the Dutch Republic during the seventeenth century, the Republic being in many ways a laboratory of modern life. In this article, three factors often mentioned as contributing to the new scientific themes are explored in the Dutch context. The first factor dealt with is the mingling of scholars and craftsmen; the second the role of the universities as centers of both teaching and research, and the third the congruence of scientific and mercantile values in the early modern Dutch trading communities.

\section{Introduction}

While the Scientific Revolution of the seventeenth century is widely acknowledged as one of the decisive transformations in world history, few historians of science would dare state this really was a revolution; or even that it was a revolution in science. The historical importance of the radical shift in our view of the natural world that occurred in the early modern period is not in dispute: but everything else is. The more we know about the Scientific Revolution, the less we feel sure that there really was a single movement in intellectual history that can be labelled as such. ${ }^{1}$

The easiest way out would of be to stop using the term altogether. But this would not solve the problem: we would still face the need to analyse and explain the fundamental changes in the perception of the natural world in the early modern period. A better way to address the problem is to study these changes within a geographically restricted or 'national' context. Within the context of a specific cultural or political and institutional region, the 'span of control' is simply smaller than in Europe as a whole (assuming that the 'Scientific Revolution' was a European event). Knowledge is always produced 